\title{
SITUATIONAL ANALYSIS OF KNOWLEDGE AND USE OF ICT IN AGRICULTURE AND ALLIED SECTORS
}

\section{S. DEEPIKA ${ }^{1 *}$, K. A. JEYAKUMAR ${ }^{2} \&$ M.JEGADESSAN ${ }^{3}$}

1* Senior Research Fellow, Department of Social Science,

Agricultural College and Research Institute, Kudumiyanmalai, Tamil Nadu Agricultural University

${ }^{2}$ Professor and Head, Department of Extension Education and Communication Management, Community Science College \& Research Institute, Tamil Nadu Agricultural University

${ }^{3}$ Assistant Professor, Department of Social Science,

Agricultural College and Research Institute, Kudumiyanmalai, Tamil Nadu Agricultural University

\begin{abstract}
In India agriculture is one of the most important sectorsand it helps to increase the livelihood of the farmers.ICT gives the needed information at the right time to the farmers. To ascertain the inevitability of ICT use in technology transfer in agriculture and its diffusion among the villages are the prime objectives of this study. 100 farm women were selected using a random sampling method in three villages namely Mariyammalkulam, Kalvellipatti, Vaikashipatti of Alanganallur block of Madurai district, Tamil Nadu. The situational analysis tool is used to test the perceived knowledge and use of ICT in agriculture and allied sector. The results showthat 97 per cent of the respondents use television, followed by mobile (95 per cent) for their information. Mobile phone is one of the essential and most frequently used ICT tool. Compactness, easy to handling and quick access to get information it may seems to be the reason for usage of mobile phone. The major factors thatinfluenceownership of ICT tools were education, mass media exposure and family income.

KEYWORDS: ICT Tools, Agriculture, Farmers, Technology Transfer.
\end{abstract}

Received: Nov 05, 2020; Accepted: Nov 25, 2020; Published: Dec 22, 2020; Paper Id.: IJESRDEC20201

\section{INTRODUCTION}

Agriculture is the main pillar and it helps to increase the overall development for Indian country. Nowadays ICT act as vital role in agriculture. It helps to disseminate the information rapidly and also helps to deliver the information at right time whenever the farmers want. Application of ICT in agriculture is augmentation of agricultural and rural development in India. ICT which provides the day-to-day information to the people based on their requirement. Enormous data and information can be effectively generated, stored, analysed, disseminated and used to upgrade agriculture by the inclusion of ICT. It helps to providing prompt, reliable and locality based information for increase the production to the farmers. We all knowhow ICT helped during Pandemic period. Mainly college \& schools students and IT field workers were heavily dependent on mobile phone for their online classes andother needs.

Traditional agriculture has been rehabilitated through the introduction of information and communication technologies and at last, it is help to increase in agricultural productivity and sustainability. To get accurate information at right time and place is necessary for increasing the efficiency and capability of small and marginal farmers(National Policy for Farmers, 2007).

e- Agriculture is one of the ICT tool and innovative way of lift the people to increase the standard of living. It 
puts emphasis on the agricultural growth and rural development through the improved data and communication process. People were collected every information from ICT. In agriculture sector, ICT helps to provide the information from growing crops tomarketing.ICT can be construed broadly as "using electronic means for processing and disseminating information and thereby facilitating communication quickly and easily".

Colle(2010) stated that among the ICT tools, mobile phones has impressive penetration in most of the developing countries altering the agricultural communication process .Mobile phones have made compact, handy, quick access to get information and readily accessible with personal communication in developing as well as in industrial countries.

During the pandemic situation ICT tools serve as the best platform to transfer the information to the beneficiaries. ICT has unquestionably played an important role in giving all the necessary information regarding crop production, pest management, drought management, an arrangement of storage facilities and marketing of agricultural commodities to ensure the livelihood of farmers based on their needs. This paper explores the perceived knowledge of farmers regarding ICT tools and how ICT tools were used in agriculture and allied sectors for rural areas.

\section{METHODOLOGY}

All India co-ordinated research project on Home science was considered as an implement to improve a research and extension is being executed through its 11 centres situated in various state agricultural universities for increasing the superiority of life of farm families in rural level. This project mainly emphasis on the empowerment of farm women by addressing the area specific difficulties and requirements of farm women in agriculture. Extension education component established out of multi disciplinary approach aims to help farming groups by distributing the latest innovative technologies to uplift the status of livelihood of farmers and farm women.

The woman was chosen by the household, even though the man was household head because to address the questionnaire if she desired to. As well, the women who viewing information through ICTs for the household. The respondents of 100 farm women were selected using random sampling method in three villages namely Mariyammalkulam, Kalvellipatti, Vaikashipatti of Alanganallur block of Madurai district, Tamil Nadu. Data pertaining to the situational analysis and use of ICT in agriculture and allied sectors are gathered by structured interview.

The situation analysis was carried out based on the criteria such as the age of the respondents, community, educational qualification, marital status, occupation, type and size of family, Organizational participation, mass media ownership and frequency of use, extension contact, availability and accessibility to different ICTs hardware, ownership of mobile, awareness and use of different ICT tools and services, the pattern of use of mobile, frequency of use of different ICT tools, a purpose for using ICTs, problems associated with use of ICTs and overall attitude of respondents towards ICT.

\section{Statistical analysis}

The following statistical tools will be used for the analysis and the interpretation of the data.

- Percentage analysis

- Correlation Analysis

The above statistical procedures were performed using SPSS version 17.0 


\section{RESULTS AND DISCUSSION}

\section{Demography Characteristics of Respondents}

The profile was collected to know the basic information about the respondents and it's interconnection with other variables. All the results are interpreted using percentage analysis. The result stated that the majority (55 per cent) of the farm women were found to be middle aged (36-50 years. It is because only middle aged farm women who are having a mobile phone were chosen for this study. On the other hand the majority ( 80 per cent) of the respondents belonged to OBC category whereas 20 per cent of the respondent belongs to SC category.

In terms of educational status, one-fourth (26 per cent) of the respondents studied up to higher secondary level as well as middle school level. Eleven per cent of them were found to be graduates. The Majority (90 per cent) of them were married. Main occupation of the respondents were found to be daily wage earning (44 per cent) followed by farming (39 per cent). Majority (43 per cent) of them were found to have farm allied activities as their subsidiary occupation followed by daily wage earning (40 per cent). About two -third (66 per cent) of respondents hailed from nuclear family similarly two -third (67 per cent) of them were found to have small family. More than two - third ( 69 per cent) of the respondents were found to be the members in the organization.

More than three- fourth (76 per cent) of the respondents were found to regularly participate in the SHG activities followed by mahilamandal ( 20 per cent).Seventeen per cent of them were found to never use the radio. Sixteen per cent of the respondents were found to have the regular extension contact with NGO personnel followed by extension officer (15 per cent) and Village Level Extension Worker (15 per cent). Three- fourth (75 per cent) of the respondents never contacted the block personnel, bank personnel (74 per cent) and university personnel (66 per cent) as well as VLEW (66 per cent).
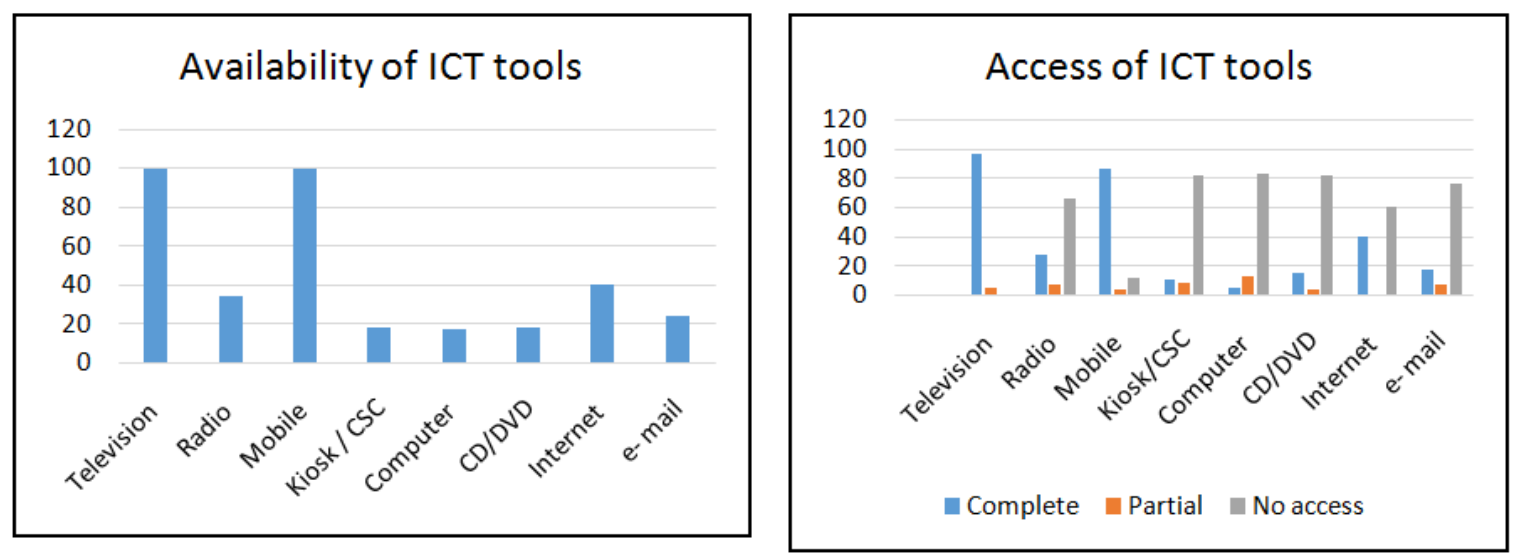

\section{Figure 1: Distribution of Respondents according to Availability and Accessibility to Different ICTs Hardware}

Availability and accessibility of ICT hardware such as television and mobile were found to be available with all (100 per cent) the farm women respondents followed by radio (34 per cent).Most of the respondents were found to have complete access to TV and mobile (96 per cent and 86 per cent) respectively. Mtega and Msungu (2013) found that ICT tools were positively influenced by using Television, mobile phone and radio in Tanzania. Whereas in India mobile phone replaced place of radio as it has portability and some phones are offering aradio in mobile phone. Mobile phone and television are the major source of information sharing to grassroots level in the study village. The only people who listen to radio are those who are commuting to work and those who don't have a data - enabled phone. 
Table 1: Distribution of Respondents According to their use of ICT Tools $(n=100)$

\begin{tabular}{|l|c|c|}
\hline \multicolumn{1}{|c|}{ Use of ICT Tools } & $\begin{array}{c}\text { With Internet } \\
\text { Service (Freq.) }\end{array}$ & $\begin{array}{c}\text { Without Internet } \\
\text { Service(Freq.) }\end{array}$ \\
\hline Mobile owned by respondent & $\mathbf{4 0}$ & $\mathbf{6 0}$ \\
\hline Family common computer /laptop & $\mathbf{1 7}$ & $\mathbf{0}$ \\
\hline Kiosk / common service centres & $\mathbf{2}$ & $\mathbf{0}$ \\
\hline
\end{tabular}

Most traditional communication media, including telephone, radio, television, paper mail and newspapers are reshaped, redefined, or even bypassed by the Internet.Internet serves as a platform to acquire crucial datato the people at the precise time. The usage of ICT tools were classified on the basis of internet connectivity. Table 1 shows that two-fifth (40 per cent) of the respondents owned mobile phones with internet service whereas majority (60 per cent) of them owned their mobile phones without internet service. The barrier of ICT in agriculture is inability to affordinternet pack cost. All those respondents possessed personal computer/ laptop had internet service facility. Reason for using mobile phone and computer were to checking commodity prices, identifying weeds or pests, and monitoring the activity of watering equipment. USDA's report revealed that consuming computer and internet access were used by 24 per cent of the farmers for purchase agricultural inputs(seeds, fertilizer, minerals and chemicals) whereas 19 per cent of the farmers used for conduct agricultural marketing activities(USDA, Farm Computer Usage and Ownership report).Common service centre used for delivering e-Services where accessibility of computers and internet was negligible to rural and remote locations. It will provide health care, education, egovernance, entertainment and other government and private related multimedia content.

Table 2: Percent Distribution of Respondents According to their Awareness \& Use of Different ICT Tools \& Services $(n=100)$

\begin{tabular}{|c|c|c|c|c|}
\hline \multirow{2}{*}{ ICT tools and Services } & \multicolumn{2}{|c|}{ Aware } & \multicolumn{2}{|c|}{ Use } \\
\hline & Yes & No & Yes & No \\
\hline \multicolumn{5}{|c|}{ Mobile without Internet } \\
\hline Calling & 100 & 0 & 100 & 0 \\
\hline SMS & 100 & 0 & 52 & 48 \\
\hline Memory stick & 42 & 58 & 33 & 67 \\
\hline Any other & 0 & 0 & 0 & 0 \\
\hline \multicolumn{5}{|c|}{ Mobile with Internet } \\
\hline Calling & 100 & 0 & 100 & 0 \\
\hline SMS & 100 & 0 & 75 & 25 \\
\hline Memory stick/ Memory card & 52 & 48 & 40 & 60 \\
\hline WhatsApp & 26 & 74 & 22 & 78 \\
\hline Facebook & 23 & 77 & 12 & 88 \\
\hline Games/ movies/ songs & 100 & 0 & 79 & 21 \\
\hline Accessing different internet sites & 26 & 74 & 11 & 89 \\
\hline Any other & 0 & 0 & 0 & 0 \\
\hline \multicolumn{5}{|c|}{ Computer /laptop without Internet } \\
\hline Office documents/presentations etc. & 10 & 90 & 10 & 90 \\
\hline Any other & 0 & 0 & 0 & 0 \\
\hline \multicolumn{5}{|c|}{ Computer/laptop with Internet } \\
\hline Office documents/presentations etc. & 20 & 80 & 13 & 87 \\
\hline Facebook, social media & 23 & 77 & 12 & 88 \\
\hline Accessing different internet sites & 26 & 74 & 11 & 89 \\
\hline Any other & 0 & 0 & 0 & 0 \\
\hline
\end{tabular}


The usability and lack of skills are major drawback found to be among the users of ICT tools like mobile, computer/ laptop and social media. From the result, 100 per cent of the respondents had the awareness of their mobile without internet for calling as well as 52 per cent of them using SMS services. More than two- fourth (42 per cent) of them aware of the memory stick with their mobile without internet. Whereas one-third (33 per cent) of them used the memory stick with their mobile without internet.

The respondents are having 100 percent awareness of their mobile with internet for calling as well as sending and receiving SMS. All of them used their mobile with internet for calling purpose followed by SMS purpose (75 per cent). More than half of them (52 per cent) had their awareness towards the memory stick with their mobile with internet. Whereas twofifth (40 per cent) of them used the memory stick with their mobile with internet facility.

More than one-fourth (26 per cent) of them were aware on social media likeWhatsApp(26 per cent) as well as accessing different sites followed by Facebook (23 per cent). All (100 per cent) of the respondents had the awareness of games /movies/songs. Four- fifth (79 per cent) of them of the respondents used their mobile with internet facility for games/ movies/ songs followed by WhatsApp (22 per cent) and Facebook (12 per cent).From the above discussion it is clear that though seepage of diffusion of mobile phone among respondents were high, it is predominantly used for entertainment such as playing games, listening songs and watching movies. So it is not advisable to share a technology through social media alone as it was used very less among the respondents. It is the SMS that too in local language may play a vital role or direct personnel calling.

Table 3: Distribution of Respondents According to Frequency of Use of Different ICT tools $(\mathbf{n}=100)$

\begin{tabular}{|l|c|c|c|c|}
\hline \multirow{2}{*}{ ICT Tools } & \multicolumn{4}{c|}{ Frequency of Usage } \\
\cline { 2 - 5 } & Always & Sometimes & Rarely & Never \\
\hline Television & $\mathbf{9 7}$ & 3 & 0 & 0 \\
\hline Radio & 9 & 10 & 31 & 50 \\
\hline Mobile & $\mathbf{9 5}$ & 4 & 1 & 0 \\
\hline Kiosk / common service centres & 1 & 1 & 27 & $\mathbf{7 1}$ \\
\hline Computer & 13 & 4 & 0 & $\mathbf{8 3}$ \\
\hline CD/VDV & 15 & 1 & 2 & $\mathbf{8 2}$ \\
\hline Internet & 25 & 10 & 5 & $\mathbf{6 0}$ \\
\hline e- mail & 16 & 3 & 5 & $\mathbf{7 6}$ \\
\hline
\end{tabular}

The frequency of the usage of ICT tools seems that overwhelming majority (97 per cent) of the respondents always use television followed by mobile phone services ( 95 per cent), based on the frequency of the usage television mostly used for entertainment, sports, recreation and news. But in the case mobile phone, it's used for personalised communication and money transfer. Muhammad et al. (2019) and Benard et al. (2019), who stated that among the ICT tools mobile phone were frequently and extremely used by rural smallholders. Compactness, easy to handling, quick access to get information, money transfer and communication it may seems to be the reason for usage of mobile phone. Mobile phone and television were user friendly and affordable than computer, and kiosk.

Table 4: Distribution of Respondents According to their Purpose for Using ICTs

\begin{tabular}{|c|c|c|c|c|c|c|c|c|c|c|c|c|c|c|}
\hline \multirow[t]{2}{*}{ ICT Tools } & \multicolumn{2}{|c|}{ Education } & \multicolumn{2}{|c|}{ Health } & \multicolumn{2}{|c|}{ Business } & \multicolumn{2}{|c|}{ Agriculture } & \multicolumn{2}{|c|}{$\begin{array}{l}\text { Social } \\
\text { Welfare }\end{array}$} & \multicolumn{2}{|c|}{ Entertainment } & \multicolumn{2}{|c|}{ Any other } \\
\hline & $\mathbf{F}$ & $\%$ & $\mathbf{F}$ & $\%$ & $\mathbf{F}$ & $\%$ & $\mathbf{F}$ & $\%$ & $\mathbf{F}$ & $\%$ & $\mathbf{F}$ & $\%$ & $\mathbf{F}$ & $\%$ \\
\hline TV & 34 & 34 & 38 & 38 & 19 & 19 & 41 & 41 & 25 & 25 & 97 & 97 & 0 & 0 \\
\hline Radio & 20 & 20 & 19 & 19 & 5 & 5 & 22 & 22 & 25 & 25 & 92 & 92 & 0 & 0 \\
\hline Mobile & 60 & 60 & 42 & 42 & 62 & 62 & 41 & 41 & 30 & 30 & 97 & 97 & 0 & 0 \\
\hline
\end{tabular}




\begin{tabular}{|l|c|c|c|c|c|c|c|c|c|c|c|c|c|c|}
\hline Kiosk/ CSC & 5 & 5 & 5 & 5 & 10 & 10 & 15 & 15 & 0 & 0 & 0 & 0 & 0 & 0 \\
\hline Computer & 10 & 10 & 5 & 5 & 14 & 14 & 10 & 10 & 0 & 0 & 25 & 25 & 0 & 0 \\
\hline CD/DVD & 5 & 5 & 10 & 10 & 5 & 5 & 10 & 10 & 10 & 10 & 50 & 50 & 0 & 0 \\
\hline Internet & 27 & 27 & 20 & 20 & 25 & 25 & 19 & 19 & 15 & 15 & 40 & 40 & 0 & 0 \\
\hline e- mail & 17 & 17 & 0 & 0 & 14 & 14 & 14 & 14 & 5 & 5 & 0 & 0 & 0 & 0 \\
\hline
\end{tabular}

(Multiple responses)

In Table4 were discussed about the purpose of ICT tools used for different sectors. It covers education, health, business, agriculture, social welfare and entertainment. Television and mobile are majorly used for entertainment purpose followed by radio (92 per cent). When compared with the other ICT tools mobile phone have more impact in sectors like business, education, health, and agriculture (62, 60 and 42 per cent) respectively. During the pandemic situation school and college students are heavily dependent on mobile phone for their online classes.Mtega and Msungu (2013), who found that increase the utilization of mobile phones as sources of agricultural information is the role of extension agents. According to Kante et al. (2018) who stated that mobile phone and radio have capability to give appropriate and proficient agricultural information and it have higher preference among rural farmers. Likewise, in agricultural sector mobile phone has used to providing information on climate, weather, market facilities and agricultural techniques to interaction with concern agencies and department (Aker, 2011).

Table 5: Percent Distribution of Respondents According to their Problems Associated with use of ICTs (n=100)

\begin{tabular}{|c|c|c|c|c|}
\hline \multirow{2}{*}{ Statements } & \multicolumn{2}{|c|}{ Yes } & \multicolumn{2}{|c|}{ No } \\
\hline & Frequency & Percentage & Frequency & Percentage \\
\hline CT Services are unaffordable & 74 & 74 & 26 & 26 \\
\hline Poor network connectivity & 86 & 86 & 14 & 14 \\
\hline Lack of awareness about ICTs & 50 & 50 & 50 & 50 \\
\hline Erratic power supply & 55 & 55 & 45 & 45 \\
\hline Lack of knowledge on operating ICTs & 45 & 45 & 55 & 55 \\
\hline Lack of training on use of ICTs & 57 & 57 & 43 & 43 \\
\hline Lack of repairing centres in the area & 42 & 42 & 58 & 58 \\
\hline High cost for repairing ICTs & 39 & 39 & 61 & 61 \\
\hline Technical illiteracy (Computer) & 54 & 54 & 46 & 46 \\
\hline Language problem & 41 & 41 & 59 & 59 \\
\hline Cultural taboos & 24 & 24 & 76 & 76 \\
\hline ICT services(Kiosks/Internet Cafe ) are faraway & 59 & 59 & 41 & 41 \\
\hline High cost of net packs & 70 & 70 & 30 & 30 \\
\hline Any other & 0 & 0 & 0 & 0 \\
\hline
\end{tabular}

Problems related to the access of ICT tools were shows that in table.5. Majority (86 per cent) of the respondents indicated that poor network connectivity was the major problem associated with the use ICTs followed ICT service are unaffordable (74 per cent) and high cost of net packs (70 per cent).

TigoKilimo(2015) found that barrier of getting information in ICT for agricultural input is inability to affordof internetpack cost. Similarly, inadequate accessibility of ICT service to the rural poor farmers, lack of skills in ICT tools and incapability of government to provide suitable ICT information to farmers (Singh et al., 2015)

Among 100 respondents, 24 respondents mentioned that they are encountering cultural taboos due to the usage of ICT tools such as watching inappropriate content in online, posting or forwarding unwanted content and abusing women. 
Table 6: Overall Attitude of Respondents towards ICT (n=100)

\begin{tabular}{|l|c|c|c|c|c|}
\hline \multicolumn{1}{|c|}{ Category } & Score range & Frequency & Percentage & Mean & SD \\
\hline Highly favourable(mean + SD) & Above 4.9 & 0 & 0 & 3.80 & 1.12 \\
\hline Favourable & $2.6-4.9$ & 99 & 99 & 3.80 & 1.12 \\
\hline Least favourable(mean - SD) & Below 2.6 & 1 & 1 & 3.80 & 1.12 \\
\hline
\end{tabular}

Almost (99 per cent) all the farm women respondents had the favourable attitude towards ICT.

Table 7: Distribution of Respondents According to their Perceived Effects of ICTs on Improving Information Access $(\mathbf{n}=100)$

\begin{tabular}{|l|c|c|c|c|}
\hline \multirow{2}{*}{ Effects } & \multicolumn{2}{c|}{ Yes } & \multicolumn{2}{c|}{ Nos } \\
\cline { 2 - 5 } & Frequency & Percentage & Frequency & Percentage \\
\hline Reduced male-female digital divide & $\mathbf{9 4}$ & $\mathbf{9 4}$ & 6 & 6 \\
\hline Improves access to agricultural inputs & $\mathbf{9 5}$ & $\mathbf{9 5}$ & 5 & 6 \\
\hline Reduces rural-urban digital divide & $\mathbf{9 4}$ & $\mathbf{9 4}$ & 6 & 4 \\
\hline Increases General Knowledge & $\mathbf{9 6}$ & $\mathbf{9 6}$ & 4 & 2 \\
\hline Helpful in time saving & $\mathbf{9 8}$ & $\mathbf{9 8}$ & 2 & 8 \\
\hline Enhanced timely feedback & 92 & 92 & 8 & 10 \\
\hline Improves quality of information & 90 & 90 & 10 & 10 \\
\hline $\begin{array}{l}\text { Improves cultural compatibility of } \\
\text { agricultural issues }\end{array}$ & 90 & 90 & 10 & 10 \\
\hline Improves record keeping & 90 & 90 & 10 & \\
\hline
\end{tabular}

According to the perceived effect on ICT tools among farm women were concluded based on their response. Most (98 per cent) of the farm women respondents perceived that ICTs were helpful in time saving followed by increasing the general knowledge (96 per cent) as well as ICTs improved the access to agriculture inputs (95 per cent). The other perceived effect of ICTs reported by most (94 percent) of the respondents was that ICTs reduced male-female digital divide as well as ICTs reduced rural - urban digital divide. Kante et al. (2017) stated that important and most perceived effects of ICT is timeliness which attribute to improve the possibility of accepting the ICT-based information of farm input. Likewise, improve the access to market information with day to day updates on the rates of agricultural merchandises in the resident markets of the nearby district is the perceived effect of ICT(K.Lokeshwari, 2016)

Table 8: Correlation between Personal and Socio-Economic Variables of the
Respondents with Attitude Towards ICT (n=100)
\begin{tabular}{|l|c|}
\hline \multicolumn{1}{|c|}{ Variables } & Correlation Coefficient \\
\hline Age & $-.65\left(^{* *}\right)$ \\
\hline Caste & .07 \\
\hline Education & .09 \\
\hline Occupation & .12 \\
\hline Family Income & .01 \\
\hline Family type & .06 \\
\hline Organizational membership & .15 \\
\hline Organizational participation & .10 \\
\hline Extension contact & .08 \\
\hline Mass media exposure & $.20\left(^{*}\right)$ \\
\hline Ownership of ICT tools & $.28\left(^{* *}\right)$ \\
\hline
\end{tabular}

Ownership of ICT tools was found to be positively correlated with the attitude towards ICT at $1 \%$ level of significance. Similarly mass media exposure was also found to be positively associated with the attitude towards ICT at $5 \%$ level of significance. According to Dixon (2009), recurrent usage and acquaintance to ICT were leads to the people for 
creating positive attitude towards ICT. Age of the respondents was found to be negatively correlated with the attitude towards ICT at $1 \%$ level of significance. Similarly, some of the result reported that age is not significant factor in defining attitude towards ICT usability (Attuquayefio\&Addo, 2016; Selwyn, 2008).

Table 9: Correlation between Personal and Socio-Economic Variables of the
\begin{tabular}{|l|c|}
\hline \multicolumn{1}{|c|}{ Variables } & Correlation Coefficient \\
\hline Age & -.087 \\
\hline Caste & .095 \\
\hline Education & $.781(* *)$ \\
\hline Occupation & .171 \\
\hline Family Income & $.261(* *)$ \\
\hline Family type & -.055 \\
\hline Organizational membership & .168 \\
\hline Organizational participation & .065 \\
\hline Extension contact & .177 \\
\hline Mass media exposure & $.413(* *)$ \\
\hline Ownership of ICT tools & $.248(*)$ \\
\hline
\end{tabular}

Based on the assessment age of the respondent hasno correlation with other variables. In terms of education, family income and mass media exposure were found to be positively correlated with the perceived effects of ICTs at $1 \%$ level of significance. Similarly Ownership of ICT tools was also found to be positively associated with the perceived effect of ICTs at $5 \%$ level of significance.

\section{CONCLUSIONS}

ICT helps to disseminate the information rapidly and also helps to deliver the information at right time whenever the farmers want. Application of ICT in agriculture is augmentation of agricultural and rural development in India through better quality information and communication process. ICT which provides the day-to-day information to the people based on their requirement.ICT has huge potentiality for agricultural and allied sectors growth and transforming the farming more interesting, profitable and enjoyable and retaining the farmers in farming and attracting the rural youth in agriculture.

This study concluded that respondents were found to have owned mobile and television (100 per cent) followed by radio (34 per cent).Poor network connectivity was the major problem associated with the use ICTs followed by its ICT service are inability to affordand high cost of net packs. The favourable attitude towards ICTs as they improved the farmers output and demonstrated improved technologies to farm women. Farmwomen perceived that ICTs were helpful in time saving followed by increasing the general knowledge as well as ICTs improved the access to agriculture inputs. Educational status leads to the exposure towards the technologies and its usability in an encouraging manner. Annual income of the family plays a key role in ownership of ICT tools. Usage of ICT tools were severely influenced by the ownership of ICT tools, education, mass media exposure and family income.

Based on results of this study, it is significant to boost the usage of ICT tools to the people in rural level, by certain approaches such as: improve the infrastructure of ICT, training to the farmers about usage of ICT tools, particularly for getting information in market. It will enhance the standard of living and social capabilities and have a positive impact on their well- 
being. Nowadays, ICT has showed to be enormously advantageous for farmers including small farmers and marginalized farmer. It assisted them in precision farming, marketing, and better-quality profits.

\section{REFERENCES}

1. National Policy for Farmers, 2007.Department of Agriculture \& Cooperation, Ministry of Agriculture, Government of India.P. 15.

2. Aker, J. C. (2011). Dial "A" for agriculture: a review of information and communication technologies for agricultural extension in developing countries. Agricultural Economics, 42(6), 631-647.

3. Attuquayefio, N. S., \&Addo, H. (2016).Gender and age comparison of information communication and technology usage among Ghanaian higher education students. American Journal of Information Systems, 4(1), 1-6. doi: 10.12691/ajis-4-1-1

4. Benard, R., Dulle, F., \& Lamtane, H. (2019). Challenges associated with the use of information and communication technologies in information sharing by fish farmers in the Southern highlands of Tanzania. Journal of Information, Communication and Ethics in Society, 18(1), 44-61.

5. Colle, D. Royal \& R. Saravanan (2010) (2010). Book Review on ICTs for Agricultural Extension: Global Experiments, Innovations and Experiences.Journal of Development Communication, 22(1).

6. BAIG, ROSHAN, R. HARILAL, and GRK SHARMA."CONSTRAINTS IN ICT UTILIZATION AMONG FIELD VETERINARIANS OF ANDHRA PRADESH."International Journal of Humanities and Social Sciences (IJHSS)5.6, Oct - Nov 2016; $93-96$

7. Dixon, K.C. (2009) Attitudes towards ICT Based Interaction: A Bachelor of Education Studies. Available from: http://www.aare.edu.au/09pap/dix091331.pdf.

8. Kante, M., Oboko, R., \& Chepken, C. (2017). Influence of perception and quality of ICT-based agricultural input information on use of ICTS by farmers in developing countries: Case of Sikasso in Mali. The Electronic Journal of Information Systems in Developing Countries, 83(9), 1-21.

9. Uchebo, Samuel Yahaya, and AminuSanni. "IMPACT OF INFORMATION AND COMMUNICATION TECHNOLOGY (ICT) ON DISTANCE LEARNING PROGRAMME OF NATIONAL TEACHERS'INSTITUTE, DEKINA STUDY CENTRE: IMPLICATIONS FOR COUNSELLING."International Journal of Electronics and Communication Engineering (IJECE) 7.2, Feb - Mar 2018, 1-8

10. Kante, M., Oboko, R., \& Chepken, C. (2018). An ICT model for increased adoption of farm input information in developing countries: A case in Sikasso, Mali. Information Processing in Agriculture, 6(1) 26-46.

11. Lokeshwari ,K.(2016).A study of the use of ICT among rural farmers, Department of Journalism and Mass Communication, Volume $6 \cdot$ Issue 3 .

12. Srinivas, T., P. PUNNA RAO, and T. VENKATA SRIDHAR."USAGE PATTERN OF ICT TOOLS BY THE FARM VARSITY STUDENTS IN INDIA." Journal of Agricultural Science and Research, 8 (5): 2330 (2018).

13. Mtega, W. P., \& Msungu, A. C. (2013). Using information and communication technologies for enhancing the accessibility of agricultural information for improved agricultural production in Tanzania. The Electronic Journal of Information Systems in Developing Countries, 56(1), 1-14.

14. Muhammad, L., Yaseen, M., Ashraf, S., Mehmood, M., \& Karim, M. (2019). Factors influencing use of information and communication technologies among farmers in rural Punjab, Pakistan. Journal of Agricultural Extension, 23(2), 1-13

15. Tomar, A., et al. "Association between socio-demographic profile and extent of use of ICT among farmers." International Journal of Agricultural Science and Research 6.6 (2016): 161-166. 
16. Selwyn, N. (2008). An investigation of differences in undergraduates' academic use of the internet. Active Learning in Higher Education, 9(1), 11-22. doi:doi/pdf/10.1177/1469787407086744.

17. Singh, K. M., Kumar, A., \& Singh, R. K. P. (2015). Role of Information and Communication Technologies in Indian Agriculture: An Overview. Available at SSRN 2570710.

18. Tomar, A., et al. "Association between socio-demographic profile and extent of use of ICT among farmers." International Journal of Agricultural Science and Research 6.6 (2016): 161-166.

19. TigoKilimo, Tanzania.2015 GSMA. Case study: Available http://www.gsma.com/mobilefordevelopment/wpcontent/uploads/2015/02/GSMA_Case_Tigo_FinalProof02.pdf 